Original Scientific Article

\title{
THE EFFECT OF ALKALINE WATER AND SODIUM ASCORBATE ON GLUCOSE AND CORTISOL LEVELS DURING ACUTE HYPERTHERMIC STRESS IN WHITE LABORATORY RATS
}

\author{
Valdrina Ajeti ${ }^{1}$, Slagjana Brsakoska², Vasilka Rendjova ${ }^{3}$, \\ Marija Angelovski ${ }^{1}$, Icko Gjorgoski ${ }^{1}$ \\ ${ }^{1}$ Department of Biochemistry and Physiology, Faculty of Natural Sciences and Mathematics, \\ Ss. Cyril and Methodius University, Skopje, R.N. Macedonia \\ ${ }^{2}$ Institute for Mathematics, Faculty of Natural Sciences and Mathematics, \\ Ss. Cyril and Methodius University, Skopje, R.N. Macedonia \\ ${ }^{3}$ Faculty of Dental Medicine, Ss. Cyril and Methodius University, \\ Skopje, R.N. Macedonia
}

Received 12 May 2021; Received in revised form 30 June 2021; Accepted 14 July 2021

\begin{abstract}
Stress can be a reason for some physiological and biological disorders in the body. The antioxidative defense system is necessary for the maintenance of redox homeostasis in the organisms. Alkaline water (AW) is in the focus of the scientific interest due to its antioxidative effect. The treatment with AW and sodium ascorbate (SA) is expected to have potential preventive effect on the organism to hyperthermic stress. The aim of this study was to investigate the effect of AW and SA on glucose and cortisol levels during acute hyperthermic stress, in white female Wistar laboratory rats. The rats were divided into three groups, each having 10 subjects. They were exposed in hyperthermic conditions ( $41^{\circ} \mathrm{C}$ ) for $80 \mathrm{~min}$, in 21 consecutive days in order to induce oxidative stress. The first group received drinkable water (control group), the second AW, and the third, AW and SA. Plasma glucose levels were determined by colorimetric method. Cortisol level was measured by the enzyme-linked immunosorbent assay method (ELISA). The means were compared using the Tukey test. Differences were considered significant at a level of $\mathrm{p}<0.05$. Our results showed that levels of glucose and cortisol were significantly higher in the group treated with AW on the $21^{\text {st }}$ day after treatment $(\mathrm{p}<0.0001)$, but not on the $7^{\text {th }}$ and $14^{\text {th }}$ day as compared to the control group. Also, co-treatment of animals with AW and SA had significantly increased the levels of glucose and cortisol on the $21^{\text {st }}$ day after treatment, indicating a synergistic effect. In conclusion, the individual action of AW or in synergism with SA caused a high protective effect on oxidative damage in white Wistar laboratory rats.
\end{abstract}

Key words: alkaline water, sodium ascorbate, hyperthermic stress, glucose, cortisol

\section{INTRODUCTION}

Alkaline water (AW) has the ability to alkalize the organism and to suppress oxidative stress related diseases, so it has attracted an increased

Corresponding author: Valdrina Ajeti, $\mathrm{Mr} . \mathrm{Ph}$

E-mail address: valdrinaajetii@gmail.com

Present address: Department of Biochemistry and Physiology, Faculty of Natural Sciences and Mathematics, Ss. Cyril and Methodius University,

Skopje, R.N. Macedonia

Phone: +38162480146

Copyright: (C) 2021 Ajeti V. This is an open-access article published under the terms of the Creative Commons Attribution License which permits unrestricted use, distribution, and reproduction in any medium, provided the original author and source are credited.

Competing Interests: The authors have declared that no competing interests exist.

Available Online First: 16 August 2021

Published on: 15 October 2021

https://doi.org/10.2478/macvetrev-2021-0023 attention over the last decade. Also, it has the ability to scavenge reactive oxygen species (ROS) (1), reduce blood glucose levels, exhibit various antineurodegenerative disease effects (2), accelerate growth, and promote metabolism (3). AW helps in disease prevention because it neutralizes free radical levels in living organisms. (4). It was reported that AW has protective effect on DNA from oxidative damage by scavenging ROS in vitro (1) and stimulates glucose uptake in muscle cells and adipocytes (5). Kim and Yokoyama have reported that the blood levels of glucose and lipid peroxide were reduced due to AW administration to Goto Kakizaki (GK) rats (6). It was also reported that the activity of hexokinase, which is a pivotal 
enzyme inducing the reduction of blood glucose levels, can be substantially increased by AW (7). AW can suppress the oxidative damage induced by alloxan (a type 1 diabetes inducer) in cells and in alloxan induced type 1 diabetes model mice $(8$, $9,10,11)$. The imbalance between production and accumulation of ROS in cells and tissues is the cause for oxidative stress which is determined by the body's detoxification ability. ROS can play several physiological roles (i.e., cell signaling), and they are by-products of aerobic metabolism. Moreover, the ROS production is greatly increased by ionizing radiations, UV, pollutants, and heavy metals which are environmental stressors and xenobiotics. This causes the imbalance that leads to cell and tissue damage (12).

Increased environmental temperatures induce oxidative stress in animals by increasing metabolic activity and oxygen consumption (13). The formation of free radicals increases significantly in conditions of hyperthermia (14). Vitamin C is a powerful non-enzymatic antioxidant capable of reacting with a wide range of biological oxidants, and it is a cofactor for a family of biosynthetic and gene regulatory enzymes. Vitamin $\mathrm{C}$ can accumulate in phagocytic cells, like neutrophils. It can strengthen chemotaxis, phagocytosis, generation of ROS, and microbial killing (15). Sodium ascorbate is a form of Vitamin C which has sodium components, lower acidity level, higher intestinal absorption, and higher body retention time. A higher oral intake of vitamin $\mathrm{C}$ can be potentially beneficial, by inducing higher reduction of ROS and lower oxidative damage in tissues (16). The chemical structure of vitamin $\mathrm{C}$ is similar to the glucose so it can replace it in many chemical reactions. Thus, it is involved in preventing the nonenzymatic glycosylation of proteins (17). Conflicting results can be found in available literature, regarding supplementation of vitamin $\mathrm{C}$ and improvement in blood glucose level and glycosylated hemoglobin (HbAlc) (18). The level of cortisol during stress was reported to be increased in wild, farm, domestic, and laboratory animals $(19,20)$. Cortisol is synthesized from cholesterol and has a variety of effects on different functions throughout the body. As an end product in the hypothalamic-pituitary-adrenal (HPA) axis, cortisol is mainly secreted in reaction to stress. It also has a key role in normal physiology (21, 22). The concentration of vitamin $C$ in the blood increases when the HPA-axis is stimulated. This observation was first noticed in 1962 by Lahiri et al. $(23,24)$. There is an inverse correlation between the ability of an animal to endogenously produce vitamin $\mathrm{C}$ and the cortisol response under stress $(15,25)$.

\section{MATERIAL AND METHODS}

\section{Animals and experimental design}

All experimental procedures were conducted in accordance with the Guiding Principles for Care and Use of Laboratory Animals accepted by the Macedonian Center for Bioethics. All protocols were approved by the Animal Ethics Committee of the University "Ss. Cyril and Methodius", Skopje, R. N. Macedonia (UP-1. NO. 2401-592) in accordance with the International Guiding Principles for Biomedical Research Involving Animals, as issued by the Council for the International Organizations of Medical Sciences. Anesthetics were applied in accordance with the EC Directive 86/609/EEC. An intraperitoneal injection of thiopental sodium (Rhone-Poulenc Rorer Limited, Nenagh, Co Tipperary, Ireland) was used to anesthetize the animals, $50 \mathrm{mg} / \mathrm{kg}$ b.wt. Wistar female rats $(\mathrm{n}=30)$, 6 months of age, weighing 210-300 g, were used for all experimental protocols. They were maintained on a 12:12 light-dark cycle and fed with standard rat chow and water ad libitum, at a thermoneutral temperature of $22{ }^{\circ} \mathrm{C}$. The experiment was conducted in 21 consecutive days.

\section{Experimental protocol}

The first group of animals (control group, $n=10$ ) was kept under conventional laboratory conditions and it received drinkable water during the entire experimental period.

The second group of animals $(n=10)$ received AW by intragastric infusion.

The third group of animals $(n=10)$ received AW and SA by intragastric infusion.

Intragastric portions of $2 \mathrm{ml}$ were applied to each animal every day in the morning during 21 consecutive days. Blood samples $(1.5 \mathrm{ml})$ were taken by tail incision, on the $7^{\text {th }}, 14^{\text {th }}$, and $21^{\text {st }}$ day of the experiment, for glucose and cortisol levels assessment. Blood serum was obtained by centrifugation at $1500 \mathrm{rpm}$ and was frozen at $-80{ }^{\circ} \mathrm{C}, 5$ minutes following sampling. On the $21^{\text {st }}$ day, five hours after the last intragastric portion, animals were exposed to a hyperthermic conditions until they reached a stage of secondary hyperthermia (body temperature of $43{ }^{\circ} \mathrm{C}$ ). The exposure was performed individually in air chambers at $40 \pm 1{ }^{\circ} \mathrm{C}$, for 80 minutes. Then, the rats 
were sacrificed by subcutaneous administration of sodium thiopental. The tissues were perfused in $0.9 \% \mathrm{NaCl}$ and instantly frozen in liquid nitrogen. All isolated materials were stored at $-80{ }^{\circ} \mathrm{C}$ until further analysis.

\section{Determination of serum glucose}

Colorimetric method was used to determine plasma glucose. The aldehyde group of glucose was condensed with ortho-toluidine in glacial acetic acid. When heated, the emitting green color was measured at $630 \mathrm{~nm}$ which was then used to determine the glucose concentration expressed in milligrams per deciliter in $100 \mathrm{ml}$ of blood.

\section{Determination of serum cortisol}

The Cortisol ELISA KIT protocol (ABNOVA, KA1885) was used to estimate cortisol. This is a solid phase ELISA based on the principle of competitive binding. It used a polyclonal rabbit antibodies directed against the cortisol molecules. The endogenous cortisol competes with a cortisolhorseradish peroxidase conjugate. Serum cortisol was analyzed in accordance with the manufacturer's instructions. On the 96-well microtitre plate $50 \mu \mathrm{l}$ of sampled serums from rats or cortisol standards $(0.1-30.0 \mathrm{ng} / \mathrm{ml})$ were transferred in the appropriate wells. The enzyme-conjugate $(50 \mu \mathrm{l})$ was added in each of the wells, ensuring thorough mixing. We incubated the plate at room temperature with gentle mixing for $60 \mathrm{~min}$. The contents of each well were aspirated. Then, four rinses with $300 \mu$ l wash solution were applied. In each well $200 \mu \mathrm{l}$ of substrate was added. It was incubated at room temperature for $30 \mathrm{~min}$. With the addition of $50 \mu \mathrm{l}$ stop solution, the reaction was stopped. The absorbance was immediately read at $450 \mathrm{~nm}$. All standards, controls, and samples were analyzed in duplicates. The results were calculated using a 4-parameter logistics curve fit.

\section{Statistical analysis}

Variables were expressed as mean values \pm standard deviation (SD). One way ANOVA was used to compare group means. Also, two-sample t-test and Principal Component Analysis (PSA) were used. The means were compared using the Tukey test. The level of significance was considered at $\mathrm{p}<0.05$. The statistical software package Addinsoft (2021) XLSTAT statistical and data analysis solution, New York, USA, (https://www.xlstat.com) was used for the analyses.

\section{RESULTS}

All comparisons showed significant differences after $21^{\text {st }}$ day of treatment. However, the correlation matrices showed none or small positive correlations. Significant correlations were observed between values in the control group after the $21^{\text {st }}$ day. The serum glucose and cortisol levels are shown in Table 1 and Table 3. The comparison of glucose and cortisol serum levels among groups is shown in Tables 2 and 4.

\section{Glucose}

The results showed that the glucose levels were higher in the group of animals treated with AW at day $21^{\text {st }}$ after treatment $(\mathrm{p}<0.0001)$, but not at day $7^{\text {th }}$ and $14^{\text {th }}$, compared to the control group. The group treated with AW and SA had significantly higher glucose levels at $21^{\text {st }}$ day after the treatment.

\section{Cortisol}

The results showed that levels of cortisol have increased in the group of animals treated with AW at day $21^{\text {st }}$ after treatment $(\mathrm{p}<0.001)$, but not at the $7^{\text {th }}$ and $14^{\text {th }}$ day as compared to the control group. Also, co-treatment of animals with AW and SA significantly increased the cortisol levels on the $21^{\text {st }}$ day $(\mathrm{p}<0.0001)$.

Table 1. Glucose serum levels mean \pm standard deviation $(\mathrm{mmol} / \mathrm{l})$

\begin{tabular}{lccc}
\hline Groups & $\mathbf{7 ~ d a y s}$ & $\mathbf{1 4}$ days & $\mathbf{2 1}$ days \\
\hline Control & $4.670 \pm 0.691^{\mathrm{a}}$ & $4.670 \pm 0.691^{\mathrm{a}}$ & $4.670 \pm 0.691^{\mathrm{a}}$ \\
AW & $4.590 \pm 0.682^{\mathrm{a}}$ & $4.970 \pm 0.672^{\mathrm{a}}$ & $6.910 \pm 0.428^{\mathrm{b}}$ \\
AW+SA & $4.280 \pm 0.437^{\mathrm{a}}$ & $4.620 \pm 0.426^{\mathrm{a}}$ & $8.850 \pm 0.679^{\mathrm{c}}$ \\
\hline
\end{tabular}

Significant differences $\mathrm{p}<0.05$ of values in the same column are marked with different superscripts

Table 2. Serum glucose correlations between AW and $\mathrm{AW}+\mathrm{SA}$ groups at 7,14 , and 21 days following treatment

\begin{tabular}{lccc}
\hline Groups & $\begin{array}{c}\text { AW+SA } \\
\text { 7 days }\end{array}$ & $\begin{array}{c}\text { AW+SA } \\
\text { 14 days }\end{array}$ & $\begin{array}{c}\text { AW+SA } \\
\text { 21 days }\end{array}$ \\
\hline AW 7 days & 0.242 & - & - \\
AW 14 days & - & 0.181 & - \\
AW 21 days & - & - & $<0.0001^{*}$ \\
\hline
\end{tabular}

Significant differences $\mathrm{p}<0.05$ of values in the same column are marked with different superscripts 
Table 3. Cortisol serum levels mean \pm standard deviation $(\mu \mathrm{g} / \mathrm{dl})$

\begin{tabular}{lccc}
\hline Groups & $\mathbf{7 ~ d a y s}$ & $\mathbf{1 4}$ days & 21 days \\
\hline Control & $0.340 \pm 0.046^{\mathrm{a}}$ & $0.340 \pm 0.046^{\mathrm{a}}$ & $0.340 \pm 0.046^{\mathrm{a}}$ \\
AW & $0.339 \pm 0.07 \mathrm{a}$ & $0.377 \pm 0.078^{\mathrm{a}}$ & $0.463 \pm 0.086^{\mathrm{b}}$ \\
AW+SA & $0.333 \pm 0.062^{\mathrm{a}}$ & $0.366 \pm 0.049^{\mathrm{a}}$ & $0.697 \pm 0.138^{\mathrm{c}}$ \\
\hline
\end{tabular}

Significant differences $\mathrm{p}<0.05$ of values in the same column are marked with different superscripts

Table 4. Serum cortisol correlations between AW and $\mathrm{AW}+\mathrm{SA}$ groups at 7,14 , and 21 days following treatment

\begin{tabular}{lccc}
\hline Groups & $\begin{array}{c}\text { AW+SA } \\
\text { 7 days }\end{array}$ & $\begin{array}{c}\text { AW+SA } \\
\text { 14 days }\end{array}$ & $\begin{array}{c}\text { AW+SA } \\
\text { 21 days }\end{array}$ \\
\hline AW 7 days & 0.831 & - & - \\
AW 14 days & - & 0.699 & - \\
AW 21 days & - & - & $<0.0001^{*}$ \\
\hline
\end{tabular}

Significant differences $\mathrm{p}<0.05$ of values in the same column are marked with different superscripts

\section{DISCUSSION}

It was demonstrated that oxidative stress is associated with a variety of disorders including diabetes, hypertension, neurodegenerative diseases, and atherosclerosis (26). Diabetes is one of the major metabolic disorders, characterized by hyperglycemia, inflammation, and insulin resistance (27). These complications are believed to be related to ROS and oxidative stress. The use of AW was suggested to alleviate these effects. It was shown that by activating hexokinase, the administration of AW to rats decreased the concentration of blood glucose and lipid peroxide levels (7). The effect on glycemia and lipidemia was demonstrated in OLETF rats (a model of spontaneous type 2 diabetes) (28). During 32 weeks of supplementation, AW stimulated growth, decreased blood glucose, cholesterol, and triglyceride concentrations by 10\%-20\%, compared to the control rats supplemented with tap water. Moreover, Li et al. (8) have concluded that AW can prevent alloxan induced apoptosis in vitro. The effect can be applied in order to suppress diabetes in experimental animals by feeding for prolonged periods of time (11). Furthermore, the results of another study from testing the effectiveness of AW in the group of streptozotocin induced mice, showed that blood glucose levels can be significantly reduced with AW. Also, glucose tolerance in diabetic mice can be improved (both models mice that were genetically diabetic) (29). These data suggest that AW can be used as an effective antidiabetic drug.

The results of our study are in accordance with the previous studies, which report that such properties of AW are shown in the second group, where acute hyperthermic exposure on the $21^{\text {st }}$ day significantly $(\mathrm{p}<0.001)$ increased glucose levels compared to the control group. Also, co-treatment of animals with AW and SA significantly increased the levels of glucose at $21^{\text {st }}$ day after the treatment.

Vitamin C can replace the glucose in many chemical reactions due to their similar chemical structure. Thus, it is effective in preventing nonenzymatic glycosylation of proteins (17). Sreemantula et al. have demonstrated that the L-ascorbic acid has produced hypoglycemic activity in a dose-dependent manner during a diabetic condition (30).

An imbalance in physiological responses can be induced by stress, which is associated with the activation of the hypothalamo-pituitaryadrenocortical (HPA) axis. As a result, increased levels of circulating glucocorticoids (cortisol and corticosterone) can be observed, being the main markers of stress $(31,32)$. McCabe et al. reported that anxiety can be reduced with a sustained release of high dose vitamin $\mathrm{C}$ by alleviating the increased blood pressure as a response to stress (33). In addition, one of the primary hormones that define stress conditions is certainly cortisol. It is known that it increases during stress conditions (34).

In the same way, the results of our study showed that the cortisol levels were significantly higher in the group of animals treated with AW on the $21^{\text {st }}$ day after treatment $(p<0.001)$. Also, co-treatment of animals with AW and SA resulted in significantly increased cortisol levels on the $21^{\text {st }}$ day $(p<0.0001)$, showing a synergistic effect of these treatments. For reducing the stress and especially its negative effects, vitamin $\mathrm{C}$ or $\mathrm{AW}$ treatments are effective $(1,35)$. Our study shows that treatment of animals with both AW and SA significantly increased the levels of cortisol on the $21^{\text {st }}$ day $(\mathrm{p}<0.05)$, as compared to the group of animals treated with AW.

In conclusion, accumulating evidence has shown that $\mathrm{AW}$ and vitamin $\mathrm{C}$ are beneficial to the health. They suppress oxidative stress related diseases (diabetes, cancer, atherosclerosis) and neurodegenerative diseases. The essential part of the stress response is the increased production and secretion of vitamin C. The increasing cortisol production could be explained as compensating 
mechanism for the ascorbic mutants (36). High levels of cortisol are a function of vitamin $\mathrm{C}$ deficiency. This is an alternative hypothesis, which comes from the inverse relationship of cortisol levels with vitamin C status.

\section{CONCLUSION}

The present study showed that the individual action of AW as well as in synergism with SA did not lead to significant changes in serum glucose and cortisol activity during the absence of high ambient temperature. They were effective in increasing the glucose and cortisol level during hyperthermic stress, causing a high protective effect on oxidative damage. So, the effect of oxidative cleavage is less pronounced in rats treated with AW and SA, because they have a stronger antioxidant defense that prevents oxidative modification of all biomolecules in the body.

\section{CONFLICT OF INTEREST}

The authors declare that they have no potential conflict of interest with respect to the authorship and/or publication of this article.

\section{ACKNOWLEDGMENTS}

This research was supported by the Faculty of Natural Sciences and Mathematics, Ss. Cyril and Methodius University in Skopje.

\section{AUTHORS' CONTRIBUTIONS}

VA and IGJ conceived and designed this research and performed the experiments. SB, VR and VA carried out data analysis. VA wrote the manuscript. VA and MA supervised the project. VA and IGJ reviewed and edited the manuscript.

\section{REFERENCES}

1. Shirahata, S., Kabayama, S., Nakano, M., Miura, T., Kusumoto, K., Gotoh, M., Hayashi, H., et al. (1997). Electrolyzed-reduced water scavenges active oxygen species and protects DNA from oxidative damage. Biochem Biophys Res Commun. 234, 269-274.

https://doi.org/10.1006/bbrc.1997.6622

PMid:9169001
2. Kashiwagi, T., Hamasaki, T., Kabayama, S., Takaki, M., Teruya, K., Katakura, Y., et al. (2005). Suppression of oxidative stress-induced apoptosis of neuronal cells by electrolyzed reduced water. In: Gòdia F., Fussenegger M. (Eds.), Animal cell technology meets genomics. ESACT Proceedings, Vol 2. (pp. 257-259). Dordrecht: Springer https://doi.org/10.1007/1-4020-3103-3_50

3. Watanabe, T. (1995). Effect of alkaline ionized water on reproduction in gestational and lactational rats. J Toxicol Sci. 20, 135-142.

https://doi.org/10.2131/jts.20.135

PMid:7473891

4. Hanaoka, K. (2001). Antioxidant effects of reduced water produced by electrolysis of sodium chloride solutions. J Appl Electrochem. 31, 1307-1313. https://doi.org/10.1023/A:1013825009701

5. Oda, M., Kusumoto, K., Teruya, K., Hara, T., Maki, S., Kabayama, S., et al. (1999). Electrolyzed and natural reduced water exhibit insulin-like activity on glucose uptake into muscle cells and adipocytes. In: A. Bernard, B. Griffiths, W. Noe, F. Wurm (Eds.), Animal cell technology: Products from cells, cells as products. (pp. 425-427). Dordrecht: Kluwer Academic Publishers

https://doi.org/10.1007/0-306-46875-1_90

6. Kim, J.M., Yokoyama, K. (1997). Effects of alkaline ionized water on spontaneously diabetic GK-rats fed sucrose. Korean J Lab Anim Sci. 13, 187-190.

7. Watanabe, T., Kishikawa, Y., Shirai, W. (1997). Influence of alkaline ionized water on rat erythrocyte hexokinase activity and myocardium. J Toxicol Sci. 22, 141-152.

https://doi.org/10.2131/jts.22.2_141

PMid:9198011

8. Li, Y.P., Nishimura, T., Teruya, K., Maki, T., Komatsu, T., Hamasaki, T., et al. (2002). Protective mechanism of reduced water against alloxaninduced pancreatic $\beta$-cell damage: scavenging effect against reactive oxygen species. Cytotechnology 40(1-3): 139-149.

9. Li, Y.P., Teruya, K., Katakura, Y., Kabayama, S., Otsubo, K., Morisawa, S., et al. (2005). Effect of reduced water on the apoptotic cell death triggered by oxidative stress in pancreatic $\beta$ HIT-T15 cell. In: Gòdia F., Fussenegger M. (Eds.), Animal cell technology meets genomics. ESACT Proceedings, Vol 2. (pp. 121-124). Dordrecht: Springer https://doi.org/10.1007/1-4020-3103-3_21 
10. Li, Y.P., Hamasaki, T., Nakamichi, N., Kashiwagi, T., Komatsu, T., Ye, J., et al. (2011). Suppressive effects of electrolyzed reduced water on alloxaninduced apoptosis and type 1 diabetes mellitus. Cytotechnology 63(2): 119-131.

https://doi.org/10.1007/s10616-010-9317-6 PMid:21063772 PMCid:PMC3080478

11. Li, Y.P., Hamasaki, T., Teruya, K., Nakamichi, N., Gadek, Z., Kashiwagi, T., et al. (2012). Suppressive effects of natural reduced waters on alloxaninduced apoptosis and type 1 diabetes mellitus. Cytotechnology 64, 281-297. https://doi.org/10.1007/s10616-011-9414-1 PMid:22143345 PMCid:PMC3386384

12. Pizzino, G., Irrera, N., Cucinotta, M., Pallio, G., Mannino, F., Arcoraci, V., Squadrito, F., et al. (2017). Oxidative stress: harms and benefits for human health. Oxid Med Cell Longev. 2017, 8416763.

https://doi.org/10.1155/2017/8416763

PMid:28819546 PMCid:PMC5551541

13. Halliwel, B., Gutteridge, J.M.C. (1989). Free radicals in biology and medicine. New York: Oxford University Press

14. Hall,D.M.,Buettner, G.R.,Matthes, R.D.,Gisolfi,C.V. (1994). Hyperthermia stimulates nitric oxide formation: electron paramagnetic resonance detection of NO-heme in blood. J Appl Physiol. 77, 548-553. https://doi.org/10.1152/jappl.1994.77.2.548 PMid:8002499

15. Webb, A.L., Villamor, E. (2007). Update: Effects of antioxidant and non-antioxidant vitamin supplementation on immune function. Nutr Rev. 65, 181. https://doi.org/10.1111/j.1753-4887.2007.tb00298.x PMid:17566547

16. Khassaf, M., McArdle, A., Esanu, C., Vasilaki, A., McArdle, F., Griffiths, R.D., Jackson, M.J. (2003). Effect of vitamin $\mathrm{C}$ supplements on antioxidant defence and stress proteins in human lymphocytes and skeletal muscle. J Physiol. 549(2): 645-652. https://doi.org/10.1113/jphysiol.2003.040303 PMid:12692182 PMCid:PMC2342961

17. Ardekani, M.A., Ardekani, A.S. (2007). Effect of vitamin $\mathrm{C}$ on blood glucose, serum lipids \& serum insulin in type II diabetes patients. Indian J Med Res. 126(5): 471-474.

18. Sargeant, L.A., Wareham, N.J., Bingham, S., Day, N.E., Luben, R.N., Oakes, S., Welch, A., Khaw, K.T. (2000). Vitamin C and hyperglycemia in the European prospective investigation into cancerNorfolk (EPIC-Norfolk) study: a population based study. Diabetes Care 23(6): 726-732.

https://doi.org/10.2337/diacare.23.6.726

PMid:10840986
19. Bashaw, M.J., Sicks, F., Palme, R., Schwarzenberger, F., Tordiffe, A.S.W., Ganswindt, A. (2016). Noninvasive assessment of adrenocortical activity as a measure of stress in giraffe (Giraffa camelopardalis). BMC Vet Res. 12, 235.

https://doi.org/10.1186/s12917-016-0864-8

PMid:27756312 PMCid:PMC5070010

20. Carnegie, S.D., Schoof, V.A., Jack, K.M. (2011). Rise to power: a case study of male fecal androgen and cortisol levels before and after a non-aggressive rank change in a group of wild white-faced capuchins (Cebus capucinus). Folia Primatol (Basel). 82(6): 299-307.

https://doi.org/10.1159/000337220 PMid:22488354

21. O'Connor, T.M., O'Halloran, D.J., Shanahan, F. (2000). The stress response and the hypothalamic-pituitaryadrenal axis: from molecule to melancholia. QJM. 93, 323-333.

https://doi.org/10.1093/qjmed/93.6.323

PMid:10873181

22. Aminkeng, F., Ross, C.J.D., Rassekh, S.R., Hwang, S., Rieder, M.J., Bhavsar, A.P., Smith, A., et al. (2016). Recommendations for genetic testing to reduce the incidence of anthracycline-induced cardiotoxicity. Br J Clin Pharmacol. 683-695.

https://doi.org/10.1111/bcp.13008

PMid:27197003 PMCid:PMC5338111

23. Lahiri, S., Lloyd, B.B. (1962). The form of vitamin C released by the rat adrenal. Biochem J. 84, 474-477. https://doi.org/10.1042/bj0840474 PMid:14461598 PMCid:PMC1243699

24. Lahiri, S., Lloyd, B.B. (1962). The effect of stress and corticotrophin on the concentrations of vitamin $\mathrm{C}$ in blood and tissues of the rat. Biochem J. 84, 478-483. https://doi.org/10.1042/bj0840478 PMid:14461597 PMCid:PMC1243700

25. Hooper, M.H., Carr, A., Marik, P.E. (2019). The adrenal-vitamin $\mathrm{C}$ axis: from fish to guinea pigs and primates. Crit Care. 23, 29. https://doi.org/10.1186/s13054-019-2332-x PMid:30691525 PMCid:PMC6348603

26. Kajiyama, S., Hasegawa, G., Asano, M., Hosoda, H., Fukui, M., Nakamura, N., Adachi, T., et al. (2008). Supplementation of hydrogen-rich water improves lipid and glucose metabolism in patients with type 2 diabetes or impaired glucose tolerance. Nutr Res. 28, 137-143. https://doi.org/10.1016/j.nutres.2008.01.008 PMid:19083400

27. Mesallamy, H.E., Suwailem, S., Hamdy, N. (2007). Evaluation of C-reactive protein, endothelin-1, adhesion molecule(s), and lipids as inflammatory markers in type 2 diabetes mellitus patients. Mediators Inflamm. 2007, 73635. https://doi.org/10.1155/2007/73635 PMid:17497038 PMCid:PMC1820618 
28. Jin, D., Ryu, S.H., Kim, H.W., Yang, E.J., Lim, S.J., Ryang, Y.S., Chung, C.H., et al. (2006). Antidiabetic effect of alkaline-reduced water on OLETF rats. Biosci Biotechnol Biochem. 70, 31-37.

https://doi.org/10.1271/bbb.70.31

PMid:16428818

29. Kim, M.J., Kim, H.K. (2006). Anti-diabetic effects of electrolyzed reduced water in streptozotocininduced and genetic diabetic mice. Life Sci. 79, 2288-2292.

https://doi.org/10.1016/j.1fs.2006.07.027

PMid:16945392

30. Sreemantula, S.,Kilari,E.K., Vardhan, V.A.,Jaladi,R. (2005). Influence of antioxidant (L-ascorbic acid) on tolbutamide-induced hypoglycaemia/ antihyperglycaemia in normal and diabetic rats. BMC Endocr Disord. 5, 2.

https://doi.org/10.1186/1472-6823-5-2

PMid:15745442 PMCid:PMC555571

31. Jamieson, D.J. (1998). Oxidative stress responses of the yeast Saccharomyces cerevisiae. Yeast 14(16): 1511-1527.

https://doi.org/10.1002/(SICI)1097-0061(199812)14:16 $<1511:: A I D-Y E A 356>3.0 . C O ; 2-S$

32. Chmelíkováa, E., Bolechová, P., Chaloupková, H., Svobodová, I., Jovicic, M., Sedmíková, M. (2019). Salivary cortisol as a marker of acute stress in dogs: A review. Dom Anim Endocrinol. 72, 1-10. https://doi.org/10.1016/j.domaniend.2019.106428 PMid:32213439
33. McCabe, D., Lisy, K., Lockwood, C., Colbeck, M. (2017). The impact of essential fatty acid, B vitamins, vitamin $\mathrm{C}$, magnesium and zinc supplementation on stress levels in women: a systematic review. JBI Database System Rev Implement Rep. 2, 402-453. https://doi.org/10.11124/JBISRIR-2016-002965 PMid:28178022

34. Haase, C.G., Long, A.K., James, G.F. (2016). Energetics of stress: linking plasma cortisol levels to metabolic rate in mammals. Biol Lett. 12(1): 20150867.

https://doi.org/10.1098/rsbl.2015.0867 PMid:26740562 PMCid:PMC4785924

35. Fumeron,C.,Nguyen-Khoa,T., Saltiel,C.,Kebede,M., Buisson, C., Drüeke, T.B., et al. (2005). Effects of oral vitamin $\mathrm{C}$ supplementation on oxidative stress and inflammation status in haemodialysis patients. Nephrol Dial Transplant. 20(9): 1874-1879. https://doi.org/10.1093/ndt/gfh928 PMid:15972322

36. Stone, I. (1979). Homo sapiens ascorbicus, a biochemically corrected robust human mutant. Medical Hypotheses 5(6): 711-721. https://doi.org/10.1016/0306-9877(79)90093-8

Please cite this article as: Ajeti V., Brsakoska S., Rendjova V., Angelovski M., Gjorgoski I. The effect of alkaline water and sodium ascorbate on glucose and cortisol levels during acute hyperthermic stress in white laboratory rats. Mac Vet Rev 2021; 44 (2): 179-185. https://doi.org/10.2478/macvetrev-2021-0023 